\title{
TRANSPORTED TO BOTANY BAY: IMAGINING AUSTRALIA IN NINETEENTH-CENTURY CONVICT BROADSIDES
}

\author{
By Dorice Williams Elliott
}

\author{
Come all young men of learning a warning take by me, \\ I'd have you quit night walking \& shun bad company, \\ I'd have you quite night walking or else you'll rue the day \\ When you are transported \& going to Botany Bay. \\ From "The Transport, or Botany Bay" (Hugh Anderson 62)
}

THE SPEAKER OF THIS BALLAD (circa 1828) laments the fact that, though he was born of "honest parents," he became "a roving blade" and has been convicted of an unspecified crime for which he has been sentenced to "Botany Bay," a popular name for Australia. Although he addresses his audience as "young men of learning," the rest of the ballad implies that he, as is conventional in the broadside form, is a working-class apprentice gone astray. Like this fictional speaker, approximately 160,000 men and women convicted of crimes ranging from poaching hares to murder - but mostly theft - were transported to one of the new British colonies in Australia between the years 1787 and 1867. ${ }^{1}$ Minor crimes such as shoplifting, which today would merit some community service and a fine, yielded a sentence of seven years, while other felons were sentenced for fourteen years to life for more serious crimes. While non-fictional accounts of the young colony of New South Wales were published in Britain almost as soon as the First Fleet arrived there in 1788, these were written by people with at least a middle-class education, whereas the vast majority of the convicted felons who were transported came from the working classes. ${ }^{2}$ Since books and newspapers were expensive and the level of literacy among working-class people varied considerably, few of them would have had access to such accounts of the new colonies. Several descriptions, mostly borrowed from the writings of the officers who accompanied the First Fleet, were published in cheap chapbook form, while occasional letters from convicts to their families were printed and distributed, and of course there were unpublished letters plus word-ofmouth reports from convicts or soldiers who did return. ${ }^{3}$ But none of these were broadly disseminated among working-class people.

What was available to most people in the working classes, however, was the ephemeral literary form known as the broadside, of which the epigraph is an example. Because 
broadsides were printed on cheap and flimsy paper, relatively few of them have survived, but of the thousands of different broadsides and ballad sheets published and distributed in the first half of the nineteenth century in Britain, there are over 140 extant that directly address convict transportation. These broadsides, which circulated widely in the streets of urban centers and in the rural districts as well, are one of the few means we have to guess how working-class people in England imagined the newly-discovered continent of Australia and the role this played in their conception of their own place as British national subjects. The broadsides demonstrate that British working-class people in the first half of the nineteenth century were developing a sense of themselves as part of the nation by imagining the new Australian colonies as an antipodal, or "other," space that defined Britain. Australia itself, however, though called up as an imaginary place, proved to be essentially unrepresentable.

"Broadside" is a printers' term that means there is print on one side of a folio-sized sheet. Broadsides could be sold as one large sheet, which is what is usually meant when the term is used. They could also be printed horizontally with one-column ballads that were cut up and sold, usually in groups of two; the term for this is "slip-sheet." The broadsides and slip-sheet ballads were sometimes collected by middle-class readers and pasted into scrapbooks, which is the primary reason that many of them are still available. I am hugely indebted to Australian historian Hugh Anderson, who gathered almost all of the existing transportation broadsides from numerous archives and published them as Farewell to Judges \& Juries: The Broadside Ballad and Convict Transportation to Australia, 1788-1868. Although Anderson's anthology includes many of the illustrations for the broadsides and some tunes for the ballads along with the texts, they are not in facsimile form so that it is not possible to see them in the way they would have been received by their original consumers. Others, including James Hepburn in his two-volume Book of Scattered Leaves, have reprinted the texts of many broadsides, including a few dealing with transportation. Roy Palmer and Martha Vicinus have published facsimile versions of some popular broadsides, while the University of Glasgow Special Collections and the Bodleian Library at Oxford University have both posted facsimile ballads online (the Glasgow site, unfortunately, is apparently no longer available). I have also examined in person virtually all of the extant transportation ballads held by the British Library, including those in the four relevant rolls of microfilm of the Sabine Baring-Gould and Thomas Crampton collection. My work would have been impossible without these collectors, both nineteenth-century and more recent; however, all of the readings of the broadsides and ballads in this paper are my own.

The broadsides that I am discussing were published at a moment - roughly 1790 to 1860 in between primarily oral folk ballads and cheap commercial literature such as penny fiction and the penny press. Broadsides of many sorts had been printed since the sixteenth century and were read by all classes of people, but when a steep tax on newspapers was instituted in 1712, the broadsides, which were not subject to this tax, became almost the only source of printed news and entertainment for the working classes (Collison 9). Further, with the advent of the iron-frame press, patented in 1800, any journeyman printer could buy a press for $£ 30$ and set himself up as a publisher (James 23). The publication and sale of broadsides, which sold for a penny or half-penny, exploded. By the beginning of the nineteenth century there were seventy-five printers selling broadsides in London alone, with many in other cities and towns as well (Vicinus 9). The number of broadsides produced increased over the next fifty years; one execution broadside from the late 1840s reportedly sold two and a half million copies, with others routinely selling in the thousands and tens of thousands 
weekly - astounding numbers for nineteenth-century publishing, where well-known novels were issued in editions of only five hundred or a thousand and even the circulation numbers of the most popular newspapers were less than 200,000 (Webb 31; Coggeshall 87-89). The popularity of the broadsides gradually faded beginning at mid-century with a reduction in the tax duties and new technological developments, including the emergence of the huge steam presses that made newspapers and books more affordable to all classes. Broadsides were printed throughout the nineteenth century, but their heyday coincided roughly with the years during which the English government was transporting many of its felons to Australia. Of course these were also the years during which England was changing from a largely rural agricultural economy to an urbanized industrial one, causing major social transformation, especially for the working classes. ${ }^{4}$

Although most accounts of print capitalism focus on newspapers, the periodical press, and novels, broadsides were part of this central economic and cultural phenomenon. Although the broadsides were part of print capitalism, their reception was not limited to print nor to any one class of people. However, the primary market to which the publishers catered was the working-class public. Even if this targeted audience did not actually buy the broadsides, the main method of marketing - using "chaunters" and other street vendors to sing or recite them in the public thoroughfares - made the broadsides and ballads an elemental part of the street life that working-class people experienced. ${ }^{5}$ Besides constantly being sung in the streets, the printed broadsides with their woodcut illustrations frequently lined the walls of pubs and were displayed in shop windows and the ballads were performed in the pubs, workplaces, cottages, and rooms that formed the environment of working-class people. This form, then, was not just a print phenomenon, nor was it primarily an oral folk tradition, but a lively combination that reached purchasers and non-purchasers alike both inside and outside their homes.

In order to meet growing demand for broadsides, printers capitalized on current events such as convict transportation to Australia as much as on traditional forms such as the folk ballad for material, often combining the two in the same broadside with only minor adjustments to the older material to update it for the new situation. The transportation broadsides, for instance, sometimes reuse older ballads about transportation to the American colonies with only slightly changed dates and descriptive details. Others are variations on the most popular broadside form, the gallows broadside, which told the story of a convict about to be hung and was often sold to the crowd assembled to watch the execution. New broadside material was written quickly according to existing conventions and rarely based on either experience or research. Both the full-sheet broadsides, combining prose and verse, and the slip-sheet ballads thus followed time-worn conventions in form and often in content but also reflected contemporary concerns. Not only were the printed versions ephemeral, but the multimedia aspect of their reception made them an infinitely variable form, one that marked the transition between oral and print popular culture.

Since broadsides formed a major, if not the only, form of reading material for the British working classes in the first half of the nineteenth century, and some of these broadsides were about convicts transported to Australia, interpreting them may provide a clue to how working-class people imagined Australia as a place and thought about transportation as an experience. Since there is no record of how working-class people actually received these texts or what opinions they developed as a result, the only viable way to discover what cultural work they accomplished is to conduct a close reading of the content and the form of the texts 
that remain. The form includes the print format, the tunes to which they were sung, and the illustrations that often accompanied them, since the broadsides were essentially multimedia events that reached across the supposed barrier of literacy to a wider audience than print alone would have made possible.

This expansion of a capitalist print medium beyond the usual limits of literacy in the broadsides worked to inculcate respectable values and prevent crime by warning workingclass consumers about the dire punishment of exile to Australia. It did so by evoking an antipodal British society where family members and friends of working-class people might exist for up to fourteen years before returning to an idealized Old Country. The broadsides also, however, subtly brought their working-class audience into the British nation as citizens who were expected to discipline themselves rather than be policed by the institutions administered almost entirely by their "betters." By portraying Australia as an essentially blank space without geography or population to which one went only in order to return, the broadsides helped to generate the loyalty and submission of a new national subject that included the working classes.

\section{The Cultural Work of the Broadsides}

IN EXAMINING THE CULTURAL WORK accomplished by the transportation broadsides, one obvious place to begin would be with the assumption that the broadsides functioned to discipline the working classes by instilling "respectable" values and threatening dire punishment for those who violated the laws - especially the stringent laws protecting property. Michel Foucault, along with a number of literary critics and historians, maintains that the period in which the broadsides were published was a time of transition between punishments based on the spectacle of brutality - primarily hanging - and newer methods aimed at reforming and rehabilitating wrongdoers into productive citizens through surveillance and discipline. ${ }^{6}$ The transportation broadsides play a complicated role in this transition. Gallows broadsides, with which they shared some characteristics, clearly participated in the spectacle of punishment by extending it beyond those who actually attended particular hangings, although the impact of the broadsides on the audience - as well as that of the hangings themselves - varied. ${ }^{7}$ Like the crowds who watched public hangings, the readers of execution broadsides might absorb the overt moral message about the sinfulness of crime and the power of the state to punish it, but they could also read the executed criminal as a hero who defied such power. ${ }^{8}$

Transportation broadsides, too, could be read in different ways, but the narrative of transportation was different from the gallows broadside. Instead of being a public spectacle, the transported convict is removed from sight altogether until he or she returns years later, almost always repentant and reformed. The broadside thus reinforces the power of the state to punish, but also focuses on the reforming effect of that punishment on the mind and behavior of the convict. In "Newgate Walls," for instance, the convicts, newly arrived in Australia, are told: "Then serve your king and country true, / And we'll behave like a friend to you" $(\mathrm{H}$. Anderson 11). The ballad ends with a return to England and a celebration of Englishness: "Fill up your glasses you sons of glee, / And drink success to sweet liberty." In such cases, it is difficult - though by no means impossible - to read the broadside as a form of resistance. In fact, while broadsides about transportation obviously involve crime, there are surprisingly few (in England) that advocate resistance to the law or changes in the makeup of society. ${ }^{9}$ 
What political resistance there is in the British transportation broadsides is usually quite subtle. For instance, the ballad that Hugh Anderson uses for the title of his comprehensive anthology of convict broadsides is "Farewell to Judges \& Juries." This particular broadside ballad appears in many collections with small variations in the title and the lyrics. One common version, though, is called "Farewell to Your Judges and Juries" (Vicinus 78; my emphasis), suggesting not only a distance between the speaker and the state's legal system, but relief at escaping from it, even if it means being banished to Australia. By adding one word, the impact of the ballad shifts from acceptance of the convict's fate to a sense of resistance. In a few of the broadsides, especially those about poachers, resentment at the laws is expressed somewhat more openly. One ballad, called "Flash Company," complains in a female voice: "Here's adieu to you judges, you are too severe, / You have banish'd my true love far from here" (Baring-Gould 4.191). It ends with an even more specific dig at the government:

\footnotetext{
If the wars should come again, what would Old England say, They would wish for the lads they have sent o'er the sea, They would wish for the transports to return back again, To fight for Old England, her rights to maintain.
}

This probably refers to the historical predicament of soldiers recently returned from the Napoleonic Wars who, unable to find employment, often ended up committing crimes. It suggests that the government is taking the wrong path in solving this problem - a path that is not only unfair to the ex-soldiers but one that the nation could come to regret. Here also "Old England" seems to be separate from the speaker and her world, since it is called "They," though "her rights to maintain" sounds like something the speaker also lays claim to as a national subject.

Surprisingly few of the transportation broadsides, however, feature actual political convicts such as the Tolpuddle Martyrs, the machine-breakers, or the Chartists, though many of them were transported. ${ }^{10}$ There are a few explicitly political British broadsides that could qualify as transportation broadsides, since they follow some of the usual conventions, often, for instance, being set at the scene of departure. One such political broadside, for example, entitled "The Sorrowful Lamentation of John Frost, and a Copy of a Letter, Which He Wrote to his Wife and Family," features a convicted Chartist leader and expresses opposition by protesting against the speaker's punishment: "A victim now am I of England's boasted laws" (H. Anderson 243). He also subtly contests the usual narrative by stressing his goodness, and thus the injustice of his conviction, but not by depicting a return to an idealized Britain; rather, he predicts his death as a convict:

\footnotetext{
My purse was always open, the poor I fed always, But now denied of pity, come death and end my days, No longer leave me here to pine in sorrow and despair But take me now O Lord I pray from this vain world of care.
}

Perhaps surprisingly, however, the broadsides did not imagine political martyrs like Frost, who were convicted of inciting rebellion at home, as likely to advocate insurrection in the penal colony. 
Indeed, most of the extant British transportation broadsides uphold the notion of a just and ideal nation; crimes - with their attendant punishments - are portrayed as aberrations that actually reinforce the justice provided by the British state, an important function in incorporating the working classes into the notion of a national subject. Most often the transported convict admits his or her guilt and acknowledges that the sentence of transportation is not only fair but merciful. One young woman convict, for example, specifically mentions her minister in a letter that was published as part of a broadside. She acknowledges both the good teaching she received and the sinfulness of her crime: "Please to give my respects to Mr. Knight, the minister that used to preach at our chapel, and tell him to talk to my wicked companions, and persuade them to turn from their evil ways, for if I had harkened to his advice, I should not be here now" (Mary Jones). In fact, if broadsides about transportation formed an important part of the "habitus" of the British working classes, to use Pierre Bourdieu's term, they not only bolstered respect for the law and the state at home, but also helped to forestall what could have been a movement toward revolution once the transported convicts arrived in their Australian "prison" (53). The penal colony was, after all, a prison without walls from which it was comparatively easy to escape - not to mention that the prisoners often worked without direct supervision, since most commonly they were "assigned" to individual masters to herd sheep and cattle or do other kinds of rural or domestic labor.

Thus, although convicts transported to Australia were not usually sent to prisons where they were subjected to modern disciplinary techniques (at least until the later stages of transportation), the focus in the broadsides is nonetheless on their reform and their repentant return to Britain. ${ }^{11}$ Importantly, the reformed convict conforms to values that were not unique to the middle classes or imposed exclusively from above, but had existed among the working classes themselves for some time, according to the evidence of the transportation broadsides that assimilated older oral ballad traditions. Historian Philip Rawlings uses the framework provided by Antonio Gramsci to argue that the hegemony of the ruling classes makes coercion of the working classes unnecessary because "the subordinate classes subscribe to a view of the world in which only the present ruling class has the right and ability to govern, and, therefore, they do not seek to challenge that right" (Rawlings14). The production of the broadsides by working-class entrepreneurs suggests that the values of what is often called "middle-class respectability" - hard work, thrift, self-improvement, cleanliness, sobriety, sexual restraint, and honesty - were not necessarily imposed from above. ${ }^{12}$ Instead, such values were inherent in most of the earlier folk ballads the broadsides incorporated. As Gramsci explains, in popular culture "certain conceptions specific to folklore remain even after these conditions have been (or seem to be) modified" (190). Thus, as a transitional form between oral folk traditions and commercial literature, the broadsides continue to express what Gramsci calls a "morality of the people"; they are not simply the product of a bourgeois morality thrust onto the working classes but at least in part a holdover from the earlier economic and cultural situations reflected in the old folk ballads, thus making it easier to assimilate the working classes into a national subjectivity that includes values shared across classes and defined simply as English.

Specifically, the transportation broadsides worked to create in their readers a sense of an English subject who not only shared respectable values with those in the classes above them, but were also loyal subjects of the crown. The broadsides did this by condemning crime, threatening potential lawbreakers with exile and suffering, and engendering a 
cross-class national identity that included allegiance to the British government, particularly to the notion of a fair and just legal system. This incipient sentiment of national identity in the broadsides is subtle but nonetheless evident. Because the broadsides functioned to create this sense of national consciousness among the at least partially illiterate working classes of the British metropole, they pose a challenge to Benedict Anderson's seminal account in Imagined Communities of a nationalism that arose first among the middle-classes of the American colonies and only later spread to European countries like England, in each case through the phenomenon of print capitalism, i.e., newspapers and the novel. The broadsides also add an additional factor to noted historian Linda Colley's account of the way that the wars with France created a sense of Britain as a united nation comprising England, Scotland, and Wales in the late-eighteenth and early-nineteenth centuries (289-325). Colley argues for the importance of a potential French invasion in solidifying a notion of French Otherness that included the working classes and thus led them, along with the middle classes, to imagine Britain as a nation and feel a sense of patriotism, although she admits that such a sense is often temporary and doesn't long survive the crisis that generated it (325). What Anderson points to is somewhat different, since he emphasizes the perhaps less intense and more subtle effects of cultural and economic forces, particularly print capitalism. For the working classes, I would argue, the process of imagining themselves as part of a nation that extended beyond the neighborhood, the village, and the region (England, Scotland, and Wales, in Colley's terms) was a result of a variety of causes, including the major historical events like war and, later, political struggles over Protestantism and Catholicism, representative government, and abolishing slavery that Colley discusses, but also literary and cultural influences like broadsides (330).

Anderson focuses on the novel and the newspaper because these forms introduced a sense of simultaneity - a "meanwhile" that constitutes "homogeneous empty time" - that he sees as essential to imagining a community, defined as a "deep horizontal comradeship" $(25,7)$. That comradeship was especially important for the English working classes during the period of convict transportation because rapid urbanization and industrialization had almost destroyed the older face-to-face connections of traditional village life for many of them. A sense of belonging to a national community was a reasonable substitution for such traditional bonds. While the broadsides do not work in precisely the same way as newspapers and novels, they do call up alternative spaces such as France (as Colley maintains) - but also Australia (33-34). If a broadside represents someone's son or lover leaving England for fourteen years and returning or writing back to warn his or her young peers, it could be said to create a rudimentary sort of "meanwhile" in which the convict lives separately and simultaneously. The sense of time in the broadsides, however, is different from a newspaper because, while the broadsides typically printed the place of publication and the publisher's name, they almost never included even the year, making it difficult to date them except by internal evidence such as reference to current events. ${ }^{13}$ The events retailed in the broadsides, then, inhabit an indistinct present that extends across years. The perception of a faraway and unknown place existing parallel to their own and in the present, occupied both by people they knew intimately and others who were like them even if unknown personally, thus allowed working-class people in England to imagine their own nation - if not the profoundly foreign space that was Australia.

Although transportation to Australia was a recurrent fact of early nineteenth-century working-class life, in the broadsides Australia itself was largely a blank space, filled in only 
with vague or erroneous notions about the new colonies and what went on there. ${ }^{14}$ In fact, according to what is now called the doctrine of terra nullius, which literally means "land of no one," Australia was legally blank or unoccupied. An 1835 proclamation by the New South Wales Governor, Sir Richard Bourke, had declared that Aboriginal people had no rights to the land, which was officially owned by the British Crown (Bourke). While this legal doctrine made way for the appropriation of indigenous land, however, the broadsides essentially erased not only the indigenous people but also the colonizers and the very geography of the Australian continent. The convict broadsides simultaneously called up a place called "Botany Bay" or "Australia" and depopulated or de-imagined it. This had the (admittedly subtle) effect of creating a sense of home in relation to an antipodal otherness that could not be described or visualized (except through the non-realistic conventions of traditional ballads) but nonetheless existed, since the readers' relatives, lovers, and friends were there.

Since one ideological function of the transportation broadsides was to bolster the idea that England was an ideal home with fair and just treatment for all, describing what convicts actually experienced or felt about Australia was not part of their aim. ${ }^{15}$ Thus the terms for the dreaded penal colonies - Botany Bay, New South Wales, Van Dieman's Land, Swan River, etc. - were merely bugaboos to frighten potential wrongdoers into conformity. For twentyfirst century readers, these names serve as one of the best ways to date the transportation broadsides, since the colonies were opened to convict settlement one by one. At the time, however, the name "Botany Bay," which has no date but was probably the most commonly used name throughout the transportation period, stood for exile, loss, suffering, and, most of all, shame. Ironically, Botany Bay was entirely imaginary as a penal colony; the First Fleet stayed there for less than eight days before abandoning it as unsuitable for settlement. In terms of literal reality, Botany Bay was an empty signifier, just as Australia was metaphorically a blank space.

What the transportation ballads emphatically did not do was portray Australia, by any of its names, as a land of promise, a place for a new life, or a space where a new nation might be built on different principles than the one they were leaving. The goal of the convict in most of the transportation ballads, as I have stressed, is simply to return to England. Thus, although one of the official reasons for the institution of transportation to Australia was that it would reform convicts and turn them into citizens who could populate a prosperous and profitable colony, the most widespread type of literature about that colony did not and could not imagine any such thing. ${ }^{16}$ Benedict Anderson observes that increased literacy contributed to the "new vernacularly imagined communities" that included the "urban and rural masses," but the transportation broadsides demonstrate that the "community" that most English working-class people became able to imagine through their newfound literacy, to which the broadsides catered, was the metropole, not the colony (79-82). Even the prospect of suffering and banishment did not lessen, but in fact strengthened, loyalty to the land and nation from which the transportees were banished. Though in fact many of them historically did stay in Australia permanently and become citizens there following their punishment, it was not until the blankness or gap that represents Australia in the broadsides was filled in for them by experience. Surviving broadsides and ballads printed or passed down through oral tradition in Australia, of course, do contain details about Australia and many of the most popular of these glorify resistance to the state represented by England. ${ }^{17}$ Surprisingly few of these broadsides and ballads, however, made it back to Britain. Even transportation ballads published in the mid- to late-century, when much more information about Australia was 
available, still primarily represent a return to England as the goal of those who are exiled, reinforcing the centrality of the "mother country" even for those expelled from it. Good behavior, not resistance, in the penal colony is thus portrayed as necessary so that the convict can return and be reintegrated into English society.

\section{Broadside Ballads and their Tunes}

GENERALLY SPEAKING, MUSIC DOES NOT portray images of places like Australia as explicitly as does the written word. This applies perhaps especially to simple tunes like those used to sing popular ballads. Music may, of course, call up imagined pictures in a listener's mind, but it usually functions more to recall scenes the listener has previously visited or read descriptions of or to create a mood or emotion than to fill in the blank of an unfamiliar place like the Australian continent with concrete details, especially since these tunes were mostly reused from older English ballads. Nonetheless, the tunes to which the transportation ballads were sung are part of the multimedia experience of consuming the broadsides and contribute to their overall ideological effect, sometimes confirming the overt message of the text but sometimes also subverting it.

Whether printed as slip-sheets or as part of full-size broadsides, the transportation ballads generally follow the conventions of other folk and street ballads, with a narrative, a ballad stanza, and a repeated chorus, though some are in rhyming couplets. Occasionally they specify a tune, though many of the tunes were interchangeable. Sometimes, though, the tunes used for broadsides did not exactly match the tone of the verbal content. Using a jaunty tune for a transport's lament, for instance, could be read as subtle form of resistance to the message expressed in the lyrics. Music historian Roy Palmer gives the example of a widely-published street ballad called "The Transport" or "Botany Bay," usually sung "in magnificent, soaring tunes"; in 1885, however, it was "rewritten for a musical play called Little Jack Sheppard" and given "a rollicking 'toora lie oora lie addity' chorus" and "a lively tune" (Palmer, Sound 148-49). ${ }^{18}$ This revision emphatically changes not only the mood but also the overt meaning of the ballad, diminishing its force as a warning or lament and turning it into a joke or at least a fate that is distanced from the audience instead of something that is immediate and feared (148).

Even if the tune remains the same, though, its relation to the text depends on the way it is performed. Most of the known tunes for the transportation ballads, as is the case with many traditional ballads, combine a catchy and memorable melody with an undertone of melancholy. The singer or musician can emphasize either the bounciness or the sadness, depending on the speed and musical dynamics or the particular quality of the voice or instruments. As they are written, however, many of the tunes do have a sing-song quality that reinforces the obligatory rhymes - often feminine or double rhymes - of the lyrics and makes them easy to commit to memory, thus subtly inculcating the "moral" of the ballads.

The tune that Hugh Anderson found for "Farewell to Judges \& Juries," for instance, is cheerful enough, with a lively beat featuring eighth-note couplets that, if sung up to speed, creates a lilting effect $(44,538)$. The melody, which is in a major key, ends on a fairly low tied D, thus concluding with a sense of resolution (Figure 1). This tune seems appropriate to the lyrics of the ballad, which, though the occasion is the speaker's transportation, is also a love ballad that imagines him obtaining riches in Australia and returning to England, thus emphasizing the cheerful idea of a return to the homeland. 
FAREWELL TO JUDGES \& JURIES

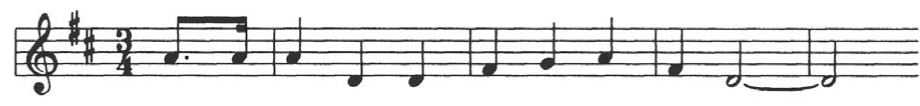

Page 44
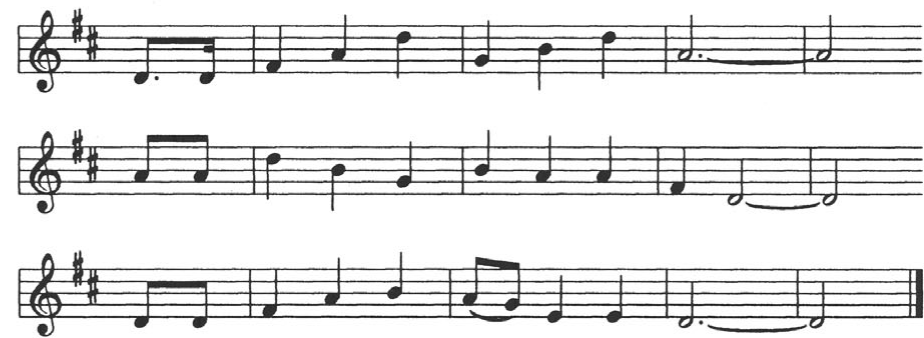

Figure 1. "Farewell to Judges \& Juries." Traditional tune. Hugh Anderson, Farewell to Judges \& Juries: The Broadside Ballad and Convict Transportation to Australia, 1788-1868 (Hotham Hill, Victoria, Australia: Red Rooster, 2000), 538. Courtesy of Hugh Anderson.

AFFECTIONATE TRANSPORT

Page 43
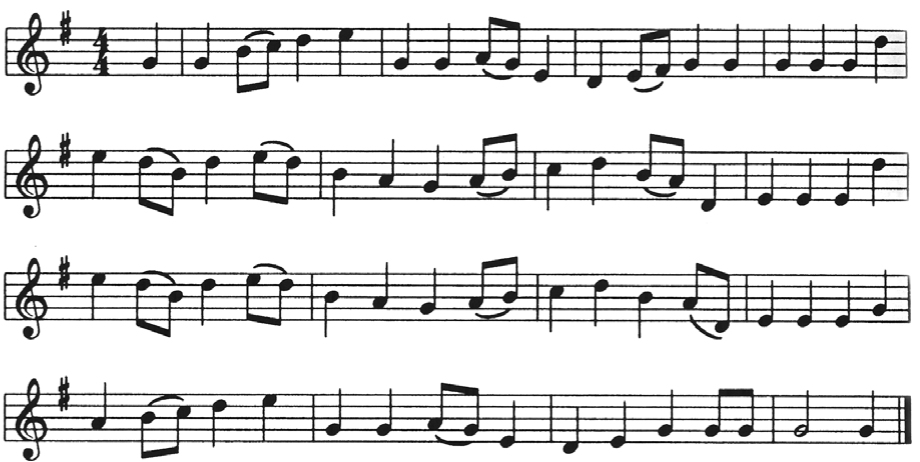

Figure 2. "The Affectionate Transport." Traditional tune. Hugh Anderson, Farewell to Judges \& Juries: The Broadside Ballad and Convict Transportation to Australia, 1788-1868 (Hotham Hill, Victoria, Australia: Red Rooster, 2000), 538. Courtesy of Hugh Anderson.

In another instance, the speaker of "The Affectionate Transport" tells a narrative of incredible ups-and-downs: it starts with his falling in love, then turning to robbery in order to buy objects to please his lover; next he is caught and sentenced to transportation, but his lover then receives a similar sentence, enabling them to reunite in Australia; they manage to escape but the woman is killed by wild animals; the speaker gets away but suffers for six days floating in a small boat on the ocean; however, he is finally rescued by a passing ship and ends up settling in America (H. Anderson 43). The tune is similarly up and down, the notes ranging over an octave and a half (538; Figure 2). Short quarter notes give the tune a lilt, but the last two measures repeat the same note five times, ending with a half-note/quarter-note measure that creates a definitive sense of resolution and finality, even solemnity.

The ballad is thus not primarily a lament but a wild and almost breathtaking adventure, so the contrast of lilting rhythm with its final resolution seems quite appropriate. Even though Australia, specifically Swan River (which dates this as a later ballad, since Western Australia 


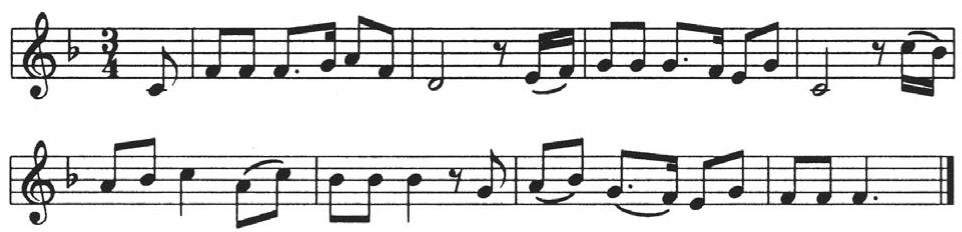

THE TRUE CONVICT MAID

Page 144

Figure 3. "The True Convict Maid." Traditional tune. Hugh Anderson, Farewell to Judges \& Juries: The Broadside Ballad and Convict Transportation to Australia, 1788-1868 (Hotham Hill, Victoria, Australia: Red Rooster, 2000), 557. Courtesy of Hugh Anderson.

did not receive transported convicts until 1850), is the reason for the ballad, it is only mentioned in two of the stanzas with vague references. The woman, for instance, is killed by "wolves and tigers," which is a conventional ballad line, wolves and tigers not being native to Australia, especially Western Australia (there is an animal called a "Tasmanian wolf" or a "Tasmanian tiger," but it is unique to Tasmania). Despite his professed warning to "Young lovers of all degree," the "Affectionate Transport" ends up safely in America with a better life, marked by the tune's melodic and rhythmic resolution. Although the protagonist does not return to England to become an English subject, neither does he imagine an Australia that is anything but a conventional place of suffering.

The lyrics of "The Convict Maid" are an unrelieved lamentation for the "grief and pain" of the woman speaking, but it has a cheery tune in a major key with a bouncy rhythm that makes it sound like a round (H. Anderson 144, 557; Figure 3). This is one of the tunes that seems not to accord with the tone of the text. One possible explanation is that the catchy tune makes the admonitory words of the ballad likely to stick in the mind; another possibility, however, is that its seemingly lighter-toned melody undermines the message of warning to women who stray from the paths of virtue and subtly mocks it. Either way, the focus of the ballad is on the crime and its consequences, not on Australia itself, even though transportation to Australia is the occasion of the ballad.

The reception of the transportation ballads thus involved not only text but music and each performance was unique. Unfortunately, detailed descriptions of such performances are extremely rare so that the experience is almost wholly unavailable to us. Besides the ordinary difficulties of "reading" a work that is two hundred years old, in the case of the ballads - and even the prose broadsides, which would often have been read aloud to a group - the number of individual performances is staggering and would have made generalization difficult even at the time. Thus it is important to remember that reading the printed texts that do survive is a very partial endeavor. Given this crucial - and very large - caveat, the existing printed versions of convict transportation ballads do nonetheless have some things to tell us about how the broadsides, together with their tunes, participated in the construction of attitudes toward crime, the penal system, and the colonizing project of empire among the largest group of people engaged in this particular colonial endeavor.

\section{The Visual Impact of the Broadsides}

BESIDES BEING SUNG, THE BROADSIDE BALLADS were often illustrated, usually with a woodcut. However, since woodcuts were much more time-consuming and expensive to 
produce than text, publishers tended to use and reuse the same set of illustrations for many different broadsides; thus the relevance of the illustration to the text is sometimes strained. In one slip-sheet version of "Farewell to Judges \& Juries," for instance, entitled "Transports and Old Baileys," the woodcut seems to be an image of someone milking a cow - something that has nothing whatever to do with the ballad printed beneath it (Bodleian, Harding B 28[238]). Interestingly, historian Patricia Anderson claims that many working-class people may have bought the ballads and broadsides primarily for the illustrations, which were the only kind of art they could afford to decorate the walls of their homes (25-27). Even if this is so, the illustrations formed a part of a reading experience and often shaped the reader's interpretation of the text and one wonders what readers made of the cow-milking illustration in conjunction with a transportation ballad.

Slip-sheet ballads about transportation often feature an image of a sailing ship, which would have been a stock illustration in any publisher's collection of woodcuts. Of course, larger publishers would have had a more varied stock of illustrations from which to draw and a few may even occasionally have had illustrations custom-made for a particular ballad, though this seems to have been rare. The print quality of an illustration was affected by how old and worn the woodcut was, with some, like the cow-milking illustration mentioned above, so worn as to be scarcely decipherable. The inappropriateness of that illustration, along with its poor print quality, suggests that the particular ballad was published by a small press with few woodcuts to choose from.

Other common illustrations include an image of a young man or boy hunting with a dog (especially for poachers' ballads) or a young man and woman either in an attitude of love or parting next to an ocean. These were a staple because they could also be used for sailors' ballads, which were also popular. Another frequently-used illustration, especially in broadsides combining prose and verse, was a courtroom scene, which has an obvious relevance to a convict transportation ballad and was also likely part of any publisher's stock, since it could also be used for gallows ballads. Courtroom scenes featured both a convict and a set of judge, jury, and lawyers; in a typical courtroom illustration the convict is situated on the left half of the page framed against a white background that makes him stand out so that his image overbalances the judge and other officials on the other half of the page (Figure 4). Such illustrations show that the accused is in the power of the court and the law, but they also mark him as the figure of most interest, which of course correlates with the focus of the ballad or narrative.

One illustration that may not seem relevant at first sight is the illustration for one version of "Farewell to your Judges and Juries" that features a building that could be a country manor, a city house, or a courthouse (Figure 5). It was obviously not custom-made for this ballad (I have seen it used on other types of ballads); it needs to be read, I think, as representing the established order - the courthouse, the home of a country magistrate who would have been the first legal representative a culprit encountered, or simply the order and calmness that the crime threatened. In any case, it seems to represent a peaceful and stable system that is in contrast to the ballad's narrative but implies that the narrative of crime cannot seriously disrupt that stability. In this case, the illustration and the text may reveal an ideological tension.

None of the woodcut illustrations I have seen, however, depict anything remotely unique to Australia or to convict experience there. The practical reason for this is probably that there were few enough transportation broadsides that no publisher would have invested in a specially-designed woodcut representing Australia or transportation directly. However, since 


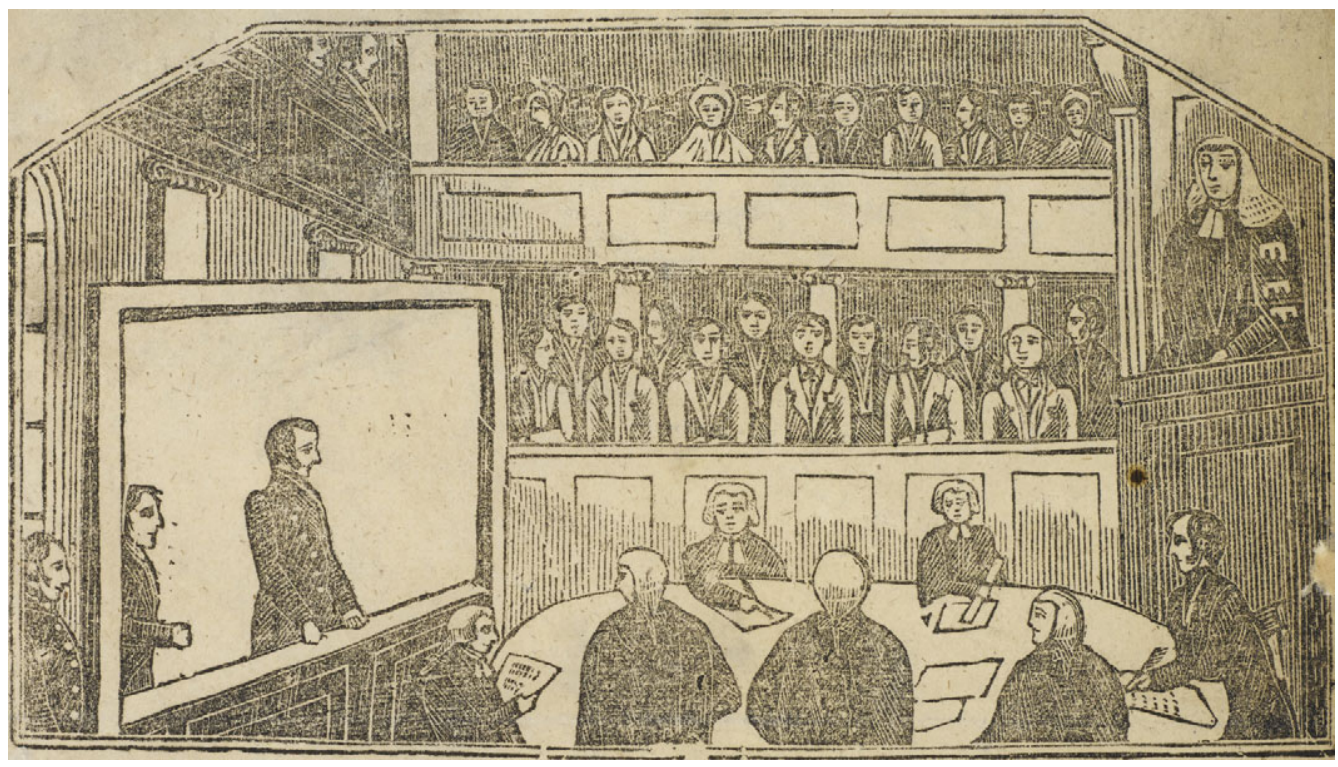

Figure 4. (Color online) "The Trial and Sentence of Mary Arnold." Illustration for broadside (Seven Dials: Paul, n.d.), pasted in Broadsides on Murder. Courtesy of British Library, (C) The British Library Board, 74.1.1888.c.3 page 7.

the illustrations were clearly key to the audience's reception of the ballads and narratives, the absence of any specific illustrations surely contributed to the sense of Australia as an empty space.

\section{Full-sheet Broadsides and Levels of Literacy}

ACCORDING TO BENEDICT ANDERSON'S ACCOUNT of the connection between nationalism and print capitalism, what prevented the urban masses from developing a nationalist consciousness in the late-eighteenth and early-nineteenth centuries, when the colonies in America were experiencing nationalist revolutions, was their lack of literacy. In England, he claims, "almost half of the population was illiterate" even by the 1840s (B. Anderson 75). However, the realization that the broadsides were actively consumed not only by the officially literate, but by a huge number of people who were only partially literate or even wholly illiterate, complicates Anderson's account. Considering the form of the full-sheet broadsides demonstrates how they could be "read" by people with varying levels of literacy.

Unlike the slip-sheets, which featured one or two ballads for a penny, the full-sheet broadsides often included prose narrative as well as illustrations plus one or more ballads. Just as prominently, the full-page broadside used headlines with varied sizes and styles of type, which both attracted attention and helped to direct the reader's eye and interpretation of the text. These larger broadsides also usually sold for a penny, which made them affordable at least occasionally for most of those who were employed and available to those not able to purchase through scenes of performance. The prose broadside, with or without 


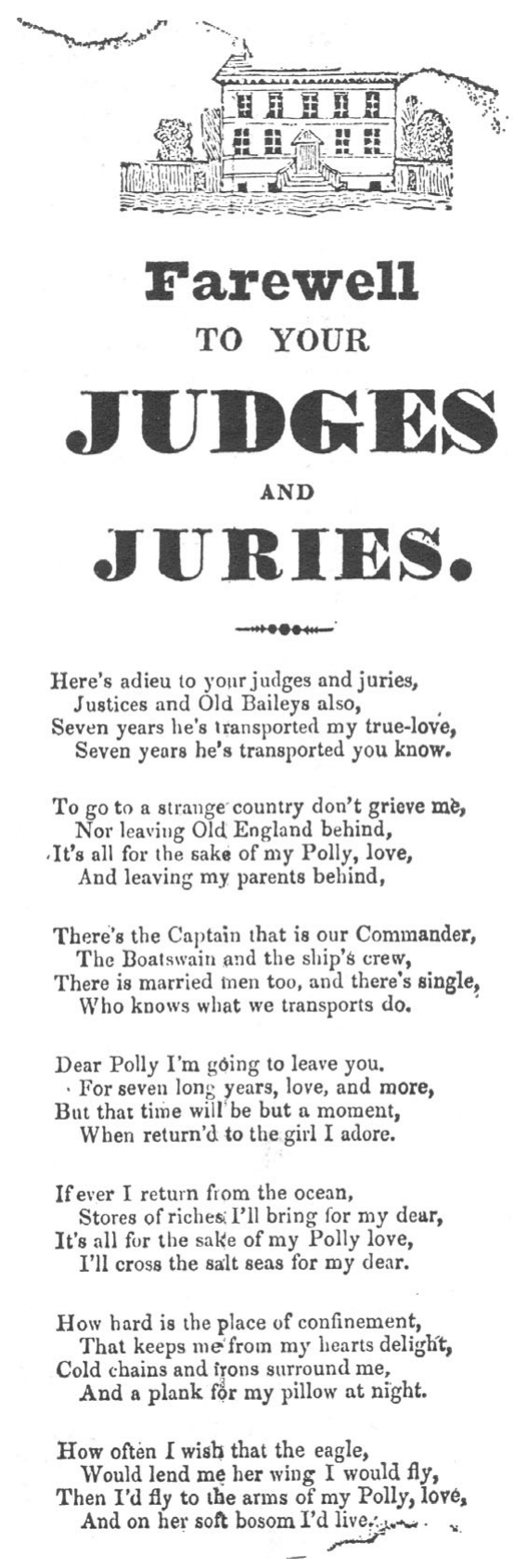

Figure 5. "Farewell to your Judges and Juries." Broadside, rpt. in Martha Vicinus, Broadsides of the Industrial North (Newcastle upon Tyne, UK: Frank Graham), 78, Plate 53. Courtesy of LCLIS Harris Lending Library, Preston, UK. 
an accompanying ballad, was the usual form for the gallows narrative and transportation broadsides often followed this form or, since they also dealt with crime and trials, appeared along with gallows narratives in the same broadside.

In Literacy and Popular Culture: England 1750-1914, David Vincent identifies three levels of literacy in the typical gallows broadside which presented

on a single page the one dramatic story in three different dimensions. The fluent reader could enjoy a compact and plainly written 250 -word account of the crime ..., those less certain of their abilities could commit to memory or have recited to them five four-line verses on the subject, and the wholly illiterate could still gain some impression of the story from the crude woodcut which adorned the page. (203-04)

Because they could be understood by those with these three different levels of literacy, argues Vincent, the printed broadsides were well-suited to a time of transition from a traditional rural agricultural economy to "burgeoning urban communities" and contributed to the "dramatic expansion in the production and consumption of imaginative literature" of this type in the first half of the nineteenth century (209). This issue of literacy is crucial in considering the ideological function of the transportation ballads to induce good behavior in convicted felons sent to Australia. By appealing even to those who were barely literate or completely illiterate through the illustrations and the tunes, the transportation ballads could extend their influence to a wider audience than any other kind of literature or printed material. To Vincent's list, I would add the large-print headlines that virtually all the full-sheet broadsides featured, since these would be easier for a partially-literate person to piece together than the densely printed text. These headlines usually summarize the main points expanded upon in the text, emphasizing key words and phrases by means of typeface and size of font, as well as printer's decorations.

A typical transported convict broadside printed by James Catnach, one of the most famous broadside publishers, displays all the different levels of literacy that Vincent and I have delineated. In "The Unhappy Transport, Or, the Sufferings of William Dale, Son of a Farmer and Gardener ... ," the title "The Unhappy Transport" is in a bold medium font in all caps across the top of the whole page (Figure 6). The rest of the headline is in smaller type, with the name "William Dale" all in caps. Below this are three more lines, in italics: "Who was put an apprentice to a Tinsmith, near Fleet-Market, where he got into Bad Company, and in a shor [sic] time went a Robbing, with a desperate Gang of Thieves, for which he was Transported Fourteen Years to New South Wales. With an account of the dreadful sufferings which he underwent, $\&$ his affectionate Letter to his Parent [sic]." This very long title uses varying fonts and sizes to encapsulate the whole story, making it more comprehensible for a semi-literate reader.

Beneath the long title are two illustrations heading two columns of text, with a printer's decoration between the illustrations to separate them, but also to make the broadside more ornamental, which would appeal to buyers looking for "art." The left illustration has a building that could be a prison in the background and what are apparently convicts pulling a cart with a strange mechanical apparatus on it. Behind the convicts, who are pulling a trace, are two wide boards arranged as a triangle, with a jagged edge on top where they meet - the shape vaguely reminiscent of the flogging "triangle" used in Australian penal settlements (though it is clearly not meant to illustrate this literally). The illustration probably represents 


\section{TH E U N H P P Y TRAN S PORT,}

Or, the Sufferings of WILLIAM DALE, Son of a Farmer and Gardener,

Who was put an apprentice to a Tinsmith, near Fleet-Market, where he got into Bud Company, and in a shor time went a Robbing, with a desperate Gang of Thieves, for which he was Transported Fourteen Years to Nens
South Wales. With an account of the dreadjui sufferings which he underwent, \& his affectionate Letter to his Parent

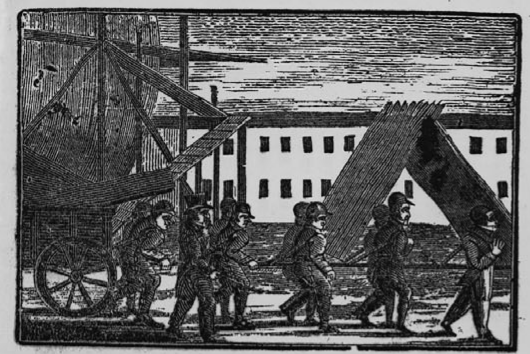

W ILL. AM DALE, was reared within 10 miles of London. When he was 14 yeurs of age, he was apprenticed to 1 Tinomith, near Fleet. Market, and for ihe first four yeal s of his appren-
ticeship tre contucted himself with such proprie tyas to become a great ticeship the conducted himself with such proprie tyas to become a great
faverite with his Master. Such was William's early prospects ; ow, unark what follows, and behold the reward of snch ns do wickedly
nnd the sure and certain punishment that awaits those who are backnnd the sure and certain punishment that awaits those who are back-
sliders from the paths of religion and honesty. It was his sad mis. fortune to form an acquaintance with a set of young, loose, idle felowk, who take delight in nothing but frequenting public-houses, and upon them. It was not long before William began to neglect his work, and stop out all night frequently. His parents remonstrated with him but in vain, he was deaf to their remonstraces, andsowent on in hs guilty career, till to crown his infamy, he turned a regular house in the eity. No words can describe the sorrows of his parents, when they becaine acquainted withthe sorrowful tidings that their once promising son was an inhabitant of Newgate charged with a capital
felony, which would, in all probability, eost him his life. When the Seasions came on they procured him the assistance of a Learned Council, but to no purpose; the facts of the case were soplain, that lee and After 7 months voyage of unspeakable hardships, th at Port Jackson, and the unhappy young man and his wrended ed companions, were immediately put to different employments. Dreadful b. were imments. first 6 months in particular. From sun-rise to sun-set his labour was unceasing, so much so that it had nearly proved fatal to his life.

Three or four years passed in this agonized and horrible state, during which time it pleased G'JD to work a wonderful change in him.- He had, through instrumentality of a kind and pions Clergy man who regularly visited them,been orought to a just sense of the wickedness of his past life, and that he had no one sense of the wiekedness of his past life, and that he had no one
but himself to blame for his degraded and melancholy situation. By frequent reading of the Holy Bible the wickedness of his life was made manifest to him, and he resolved, with the his life was made manifest to him, and he resolved, with the land, he would lead a very different life to what he had hitherto done.-The following is a Copy of a Letter, which he sent to done.-The

" parents.

"Manjfold are the sufferings which I have undergone since the

ThAW naear awhile my loving That in my trade $I$ should excell, A true a tale as e'er was penti'd,
A tring ear, (friend A true a tale as e'er was pee.
This day I bring you here.
My sufferings I will uufold,

My sufferings 1 will uufold,
My sorrows and my erime

My sorrows and my crimes,
That those who read,may take good
Unto their ways in time.

My lawful name is William Dale
Ay

An honest farmers son

My parents dear the did me zear

All wicked ways to shun,

When $\mathbf{I}$ was fifteen years of age
My parents did agree,

His Prentice for to be

My master he did lihe me well,
For 'twas my sole delight,

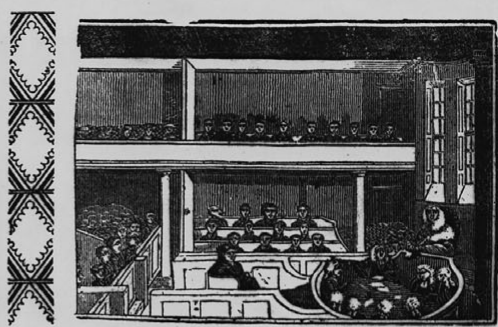

sorronofiul day of ou' parting. - O the horrors of tha t dismal day. al dismal parting, are engraven on my memory, time can never efface i.
Hovo bitterly do I novo lament the errors of my past life, and hon How bitterly do I noov lament the errors of my past life, and how
keenly do If eel the punishment which my owon misoonduct has bronght upon me.-Dearest parents, upon my knees, I crave your pardon for aever-ceasing toil, does the reconllection of yout tender love, and you anxious concern for my welf are and happiness, rusk upone, and you ed mind-then do I feel the pangs of remorse to such a degree that 1 call upon Heaven to ease me of 'ny wretched existence. O happy Eng. land. O Conntry, favoured of the LORD, how does my heart bleed at the recollection of thee, how, compared with the misery around me, enjo enjoy.- Here am 1 , in bondage, in a foreign land, far from my blessed emblem of my infamy, and diging in a dark and cheerlose nuorry from the first dawon of morn, till inge dark night, then housed ams quarry of wretches like myself; in a gloomy habitation where, after a coarse comfortiess meal, I take such repose as a broken spirit and a pallet strato can afford me. Should GOD, of his infinite goodness, enak? me to bear up under this load of nisery, and prolong my life and your
until the expiration of my Sentence, $O$ what happiness will it be to once more to see mo once more to see my native land, and to embrace my dear parents, my
sisters and brethren.- Adieu, dear pa ents. Your unhappy Son,
WILLIAM D.ME

At last the happy day arrived when poor William Dale was once more a free man; the laws demand was exacted unto the last moment, and upou the
23 rd day of March, his bonds were snapt asunder. He immediately embarked on board a vessel,and being favoured with prosperous weather, at the end of 21 weeks, hefound himself ouce more ill his native land.-He hastened home to his native cottage, and once more had the pleasure of clasping his aged
Parents to his breast. No language can deseribe the happiness which he nov feels, his family look opon him as one restored from the dead; and vie with each other in bestowing upon him proofs of their affection and regard. This is a brief outline of the history of this unfortunate young man may his fall prove a warning to mauy. Happy is the man to whom the truth is imparted, with graceessful for a time, and riot on his ill-rotten dains; but mark the life, may bo ces of it, his peace of mind is lost-to lnill conscience, he flies to ardent liquore he is fearful of being betrayed,even by his most confident associate-and acon. tinualdread of falling into the hauds of Justice,hangs like a millstone round $\mathrm{his}$ neck. Thus religiou and virtue,peace and bappiness,ars exchanged for shame misery, reproach, and infamy, imprisonment, flogging, banishment,and the gibpend upon it, a deviation from virtue is a departure from happiness

Printed and sold by J. CATN ACH, 2, 3, Monmouth-Court, 7 Diale.

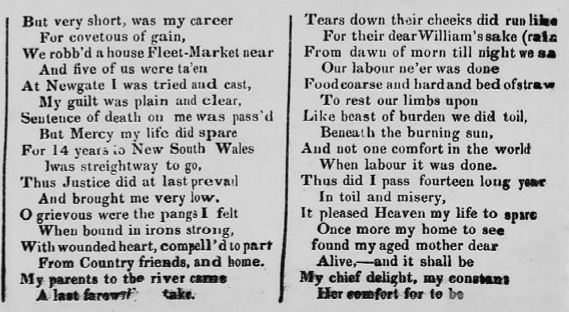

Figure 6. "The Unhappy Transport, Or, the Sufferings of William Dale, Son of a Farmer and Gardener. ..." Broadside (Seven Dials: Catnach, n.d.), pasted in Broadsides on Murder. Courtesy of British Library, (C) The British Library Board, 74.1.1888.c.3 page 57. 
prisoners from the Hulks, non-sea-worthy ships that were used as jails in England during the period, performing labor usually performed by draft animals, though it is difficult to interpret precisely. Even without a clear understanding of what the picture is meant to depict, it conveys a general sense of convicts working (pulling a trace) and suffering (the hint of the "triangle"). The courtroom scene is easier to read; it portrays the convict within a legal system that contains him within its boundaries, both in England and in his future home in an Australian colony. Yet he is given a kind of subjectivity by the white panels that make him stand out from the undifferentiated group of spectators in the upper gallery, who could be read as standing in for the viewers and readers of the broadside. Like the convict, they too are bounded by the frame of the court scene that contains them, simultaneously including and disciplining them within the legal institutions of the British nation.

The body of prose text in the middle of the broadside is densely printed and includes both a narrative about William Dale's experiences that follows the conventions for content of the transportation broadsides - but in more detail than a ballad - and a supposed letter to his parents from Australia, the letter printed in italics to separate it from the narrative portion. The narrative describes young Dale's beginnings as an apprentice, when "for the first four years of his apprenticeship he conducted himself with such propriety as to become a great favorite with his Master," and makes conspicuous the contrast of his fall into crime with "Such was William's early prospects; - ow [sic], mark what follows, and behold the reward of such as do wickedly and the sure and certain punishment that awaits those who are back-sliders from the paths of religion and honesty." William falls in with bad companions, who "have no pleasure in their business, but consider it as a grievous burden upon them," again a clear statement of the values being promoted in the broadside. He turns to drink, neglects his work, ignores his parents' remonstrance, and finally, "to crown his infamy, he turned to a regular thief." The focus through much of the narrative is on how he disappointed his parents, which is also the subject of the letter that appears within the narrative. The voyage to "Botany Bay" is described only vaguely as "7 months ... of unspeakable hardships." After "Three or four years passed in [an] agonized and horrible state" of "unceasing labour" and sufferings "dreadful beyond all description," he is converted by a clergyman and decides to reform. Words like "unspeakable" and "beyond description" both stress the extent of his suffering and leave the nature of it completely unarticulated.

A bitterly repentant letter to his parents follows. In the middle of the letter, the writer turns from his parents to apostrophize the nation: "O happy England! O Country, favoured of the LORD, how does my heart bleed at the recollection of thee, how, compared with the misery around me, how great are the comforts which even the meanest of thy inhabitants enjoy." Historically, at least after the very early starvation years of New South Wales, the inhabitants of the colonies, including the convicts, generally had a higher standard of living than many of those in England's working classes; this is not even hinted at in the narrative (Nicholas, "Care" 196). In the one sentence that does purport to actually describe his experience in Australia, he writes, "Here am I, in bondage, in a foreign land, far from my blessed shores, from friends, and kindred, and home, dragging a chain, the emblem of my infamy, and digging in a dark and cheerless quarry from the first dawn of morn, till the dark night, then housed among scores of wretches like myself, in a gloomy habitation where, after a coarse comfortless meal, I take such repose as a broken spirit and a pallet of straw can afford me." Even this more specific description, however, is primarily generic. In fact, a convict who had not committed any secondary crimes would not usually have been "dragging a chain" and 
would probably not have been working at a quarry, but rather assigned to a settler to work on a farm or a cattle or sheep station. Moreover, as Stephen Nicholas has shown, the majority of convicts in Australia were well-fed and had decent housing ("Care" 196).

In the narrative, Dale is finally able to return home, where he is honored by "his family [who] look upon him as one restored from the dead; and vie with each other in bestowing upon him proofs of their affection and regard." This is followed by a half-paragraph reiterating the warning to those who might be tempted to commit crime. What is ironic about this warning, however, is that Dale's condition at the end is portrayed as happier than his beginning, before he turned to crime. Not only does his family lavish affection and honor upon him, but he has also been brought into narrative subjectivity.

The bottom fourth of the broadside page is a ballad, which covers four columns and recounts essentially the same story as the prose narrative. It begins with a traditional invocation: "Draw naear [sic] awhile my loving friends." It tells the story in the conventional ballad stanza and meter so that it can be sung and easily memorized, even by the illiterate person who would hear the ballad instead of reading it. There are some differences in the ballad and the prose narrative, though: in the ballad, the speaker describes working "beneath the burning sun," which, although somewhat generic, would at least be true to the climate of New South Wales; when the speaker returns to England, only his mother is still alive; and the clergyman, the conversion, and the long didactic warning are left out. This suggests that the ballad was not written along with the prose narrative, but composed separately and added to the broadside because it (mostly) told the same conventional story. Of the five different versions of the story included in the broadside - the long title, the illustrations, the prose narrative, the letter, and the ballad - surprisingly it is the ballad that focuses most on the Australian experience itself, but even in that the descriptions could be adopted for any situation of transportation or hard labor. Thus, even in a broadside that includes a letter supposedly written by a convict while in Australia, the colonies there are not portrayed in any ways that are unique to that continent or very informative about what the sentence of transportation actually meant for those who received it. The clear message of all the versions of the story told in this broadside is that England is the ideal place to be and that the reader, viewer, or listener should adhere to the values that will keep him or her a law-abiding, patriotic - and free - citizen of the nation.

\section{The (Mistaken) Land of Exile}

IN VIRTUALLY ALL THE BROADSIDES, as I have emphasized, the actual land and culture of the Australian colonies is vague, absent, or inaccurate. Many of the broadsides are set at the moment of leaving and do not even attempt to portray Australia, while those that do often mix up conditions in Australia with those in the American South, the former site of convict transportation. ${ }^{19}$ In "The Unhappy Transport," which purports to be the "Life of James Revel," for instance, the broadside is given an air of authenticity by giving a specific date for Revel's transportation (February 1808) and return to England (1 March 1822). However, the ballad about Revel appears in several other pre-Australian versions featuring him as a convict transported to Virginia. ${ }^{20}$ The description of his experience in Australia is taken directly from the Virginia versions and has almost no resemblance to conditions as they existed in any of the Australian colonies. 
The Revel ballad begins conventionally: "My loving countrymen, pray lend an ear." Revel comes "of honest parents" - who gave him a good education until, at age 13, he was apprenticed to a "tin-man," after which he fell into "wicked company . . . with whom a thieving I did go." He is caught, justly sentenced to transportation, and parts from his "tender parents" with tears. All of this conforms closely to the conventions of transportation broadsides. This particular broadside, however, follows the transport through his journey of seven months and goes into some detail about what happens to him over the next fourteen years. For instance, he reports that

We at Port Jackson were all put on shore;

Then, to refresh us, we were all made clean,

That to our buyers we might better seem;

The things were given that did to each belong,

And they that had clean linen put it on....

The details about the voyage taking seven months and landing at Port Jackson do refer to Australia, as does the return of the transports' clothing once they arrive. The word "buyers," however, is the first clue that the narrative is mingled with stories of transportation to America, since Australian masters did not buy their assigned servants or pay any money to get them; they merely agreed to furnish their "government men" with board and clothing in return for their labor. At this point, "buy" might seem to be a metaphor, but a few lines later, the speaker explains that his master "bought me from the captain out of hand," something that happened in America, but not Australia, where the ships' captains were not even in charge of the convicts they transported, let alone able to sell them. ${ }^{21}$

The next section further mixes details from Australia and America: the speaker describes cold weather and being sent to the field "Amongst tobacco plants to work with a hoe." $\mathrm{He}$ works extremely long hours hoeing tobacco and grinding corn at a mill by night until he falls ill. His illness leads him to long to see his "native land once more" and he turns to God and pledges to "be a comfort to my nearest friends" if allowed to return to England. After twelve years, his master dies and,

\footnotetext{
At last a planter, who at Sidney Town did dwell, Came down to view it and he lik'd it well.

He bought the negroes who for life were slaves,

But no transported felons would he have.

So we were put like sheep into a fold,

Unto the highest bidder to be sold.
}

Although the new master is said to be from "Sidney Town," in fact there were hardly any planters in New South Wales, most of the successful immigrants making their money growing food crops or running sheep and cattle stations, not tobacco plantations. Certainly there were no African slaves "for life." Also, unless they committed secondary offenses, most transported convicts did not remain in servitude for the full number of years of their sentence; they could earn a ticket-of-leave after a few years with good conduct and then a conditional pardon, which made them free as long as they stayed in Australia. In the ballad, however, the speaker is "bought" by a kind master who promises to "not use me as a slave, 
/ But as a servant, if I'd well behave." He does so and the new master "unto me express'd much love," paying his passage back to England when his sentence expires. The speaker returns, takes good care of his now aged parents, and ends the ballad with the traditional warning to others to learn by his experience.

Like the supposed convict William Dale, the speaker of the Revel ballad prospers through good behavior and his experience of transportation, however horrific it may have been, culminates in a return to family and friends in England. This is somewhat misleading, since most convicts stayed in Australia and became part of a new economy and class system; many had a higher standard of living and were more successful than would have been possible in England. ${ }^{22}$ A few, especially before the departure of Governor Lachlan Macquarie in 1821, even became wealthy. In fact, some British officials claimed that working-class people in Britain were purposely committing crimes in order to be sent out to Australia with a free passage (Hirst 20). The broadsides, however, contradict such a notion by imagining that the transported convict will return repentant to an idealized "old country" where he or she will be quickly reassimilated into English life despite the convict "taint" or "stain" that was associated with convicts both in Great Britain and in Australia. Transportation, in fact, seems to cleanse the convicted criminal, turning him or her into a stable, upright citizen who can now warn his or her fellows against violations of just British laws and proprieties. In retrospect, the Australian colony again disappears into blankness, its function as a defining other of the English national character and purifier of those who have deviated from it having been fulfilled.

While the mingling of American and Australian conditions in the Revel ballad is literally the result of publishers who took advantage of an older transportation ballad by slightly altering it to fit a new context, their failure to excise the allusions to American slavery could also be read as a repressed reference to the indigenous Aborigines in Australia. The Aborigines are rarely mentioned in the convict broadsides, though there are a few references to "natives." In nineteenth-century England and Australia, Aborigines were known as "blacks" and the same vocabulary used for African-American slaves was often used for them, although Australia's indigenous peoples were different both racially and in their relationship to white colonizers. This slippage in the language marks the lack of understanding that most English people, especially those in the working classes, had for and about the Aborigines. In the Revel ballad the fact that the speaker, a transported convict, has to distinguish himself from the black slaves suggests the structural likeness not only between transported felons and slaves, but also between Australian convicts and Aborigines. Thus, in a situation where convicts could have united with the indigenous peoples in resistance to the English colonizers, the broadside ballad emphasizes the convict's affinity with white Englishness and difference from blackness, whether Australian or American not much mattering. This in effect creates a class in Australia that is lower even than the lowest of the working classes, giving the despised transported convicts a place above the Aborigines and a further reason to ally themselves with the English even though they have been ejected from British soil.

$* * *$

THUS, IN A TIME OF PERSISTENT working-class unrest as a result of the often brutal effects of agricultural capitalism, industrialization, and urbanization, the broadsides that formed the primary reading of the working classes served a complicated ideological function. Because 
they were multimedia productions that catered to different levels of literacy and were hence "readable" even to the lowest levels of society, they could be effective tools to reinforce respectable values and facilitate a cross-class definition of Englishness by representing those who had been expelled from England as unworthy of forming a part of the polity it supposedly represented. In order to regain a place in this idealized Old England, the transported convict was represented as needing to reform so that he or she could return, while those who remained at home were warned of the serious effects of transgressing British laws and encouraged to conform to the respectable values that were understood as shared across classes. This sense of being part of the nation thus helped to discipline both the convicts and the working classes still in England and to create a sense of pride, calling all into the service of Britain's imperial ambitions. On the other hand, the performative nature of the broadsides always left room for this ideological mission to go astray, since performers, as well as readers, could subtly alter the overt message by injecting irony or mockery into the audience's experience of the ballads or narratives. Although the broadsides were almost the only information many working-class people had about Australia, Australia itself, with its geography, climate, indigenous people, and even its penal system, was remade into a blank space - or one conflated with other colonies such as America - even as it was summoned into existence.

The University of Kansas

\section{NOTES}

1. The most popular history of convict transportation to Australia is Hughes's The Fatal Shore (1988). Some of the other major histories of the Australian transportation era include Robson (1965); Summers (1975); Shaw (1977); Frost (1980); Hirst (1983); Nicholas (1988); Brand (1990); the essays collected in Phillips and Davies (1994); Dyster (1996); Oxley, 1996; the essays collected in Duffield and Bradley (1997); Reece (2001); Brooke and Brandon (2005); and Reid (2007).

2. Two such accounts are those by Tench (1789) and Collins (1798).

3. The most famous early report about Australia supposedly by a convict was George Barrington's Voyage to Botany Bay (1793-94?). Rickard has demonstrated conclusively, however, that the narrative was not written by Barrington nor was it published with his consent. It was a hatchet job with pieces taken directly from earlier writers like Tench and Collins.

4. Evans, among many others, discusses this change (162-68).

5. Silas Wegg in Charles Dickens's Our Mutual Friend is a fictional example of a street vendor who sells and sings broadside ballads (44-53).

6. Foucault, Discipline and Punish. While others, especially historians, have questioned the specifics of his account, most agree that this was indeed a transitional period in penal theory and practice. Rowbotham gives a summary of historiography on this transition (188-91). See also, among others, Rudé, Criminal 114-15; Beattie 614; Jenkins 129-30; and Godfrey and Lawrence 76-77.

7. Henry Fielding, for instance, commented on this in his 1751 Reform Proposals (147-48).

8. Gretton gives a brief but informative discussion of "the penny capitalism of printed imagery," referring to the gallows broadsides (46).

9. Irish broadsides almost always portrayed transported convicts as political martyrs. One reason I am excluding the Irish ballads here is that they follow somewhat different conventions than those published in England, Scotland, and Wales. 
10. Rudé calculates that 3,600 or about one in forty-five of all convicts transported to Australia were convicted of crimes that were politically motivated (Protest 8-10).

11. Beginning in 1845, some convicts underwent a prison sentence in Britain before being sent to Victoria as "exiles" (see Shaw 312-34).

12. Bailey suggests that the large "rough" population of the working classes may have "performed" respectability in cross-class interactions rather than actually identifying with such values. Even in this case, however, the broadsides would be one way they learned how to perform appropriately (32-33).

13. The publication years of some broadsides have been identified by scholars from the dates or notes in the collections in which they are mostly found or from publishers' catalogs, but in general the lack of dates on the broadsides themselves makes any conclusions about changes over time difficult to make.

14. Duffield notes, for example, that upon arrival most convicts had little idea of what trades were useful or what kind of work was done in Australia ("Problematic" 21).

15. The essays collected in Frost and Maxwell-Stewart, as well as those in Duffield and Bradley, represent significant recent attempts to recover Australian convict voices in other types of texts including tattoos, convict indents, and love tokens made by scratching or engraving on coins. My project here, however, is not so much to recover convict voices themselves as to examine what British working-class audiences could have imagined about convicts and Australia.

16. A. Frost has demonstrated that the original aims for Botany Bay were not merely to dump convicts but that a strategic and economically prosperous colony with the convicts as its settlers was intended (49, 121-23).

17. Transportation ballads published in Australia follow distinctly different conventions than the British versions. For Australian broadsides, see H. Anderson, especially his collection of Jack Donahoe and other bushranger broadsides (pp. 195-215), and Ward's Penguin Book of Australian Ballads (pp. 3551). Ward also explained the key differences between British and Australian ballads in an unpublished lecture he gave in the 1950s ("Felons and Folksongs").

18. For a history of Jack Sheppard literature, see Rawlings (39-75).

19. On the earlier practice of transportation to America, see Ekirch and Coldham.

20. For a detailed discussion of American versions of this ballad, see Morgan and Rushton 89-92. This ballad is very similar to another famous transportation ballad, "Van Dieman's Land."

21. Maxwell-Stuart and Duffield also briefly discuss the differences between American and Australian versions of this ballad in "Skin Deep" (118-19).

22. Although certainly many convicts were able to ship passage back, several historians have agreed that transported convicts had "little chance of returning to England" and the majority stayed in Australia (Robson 111). Nicholas and Shergold, for instance, agree with Shaw's estimate that only about 5\% of transported convicts ever returned to Britain, though numbers were higher before 1820 ("Unshackling" 9, Shaw 143).

\section{WORKS CITED}

Anderson, Benedict. Imagined Communities: Reflections on the Origin and Spread of Nationalism. 1983. Revised ed. London: Verso, 2006.

Anderson, Hugh. Farewell to Judges \& Juries: The Broadside Ballad and Convict Transportation to Australia, 1788-1868. Hotham Hill, Victoria: Red Rooster, 2000.

Anderson, Patricia. The Printed Image and the Transformation of Popular Culture 1790-1860. Oxford: Oxford UP, 1991.

Bailey, Peter. Popular Culture and Performance in the Victorian City. Cambridge: Cambridge UP, 1998.

Baring-Gould, Sabine and Thomas Crampton, collectors. Popular Literature in Eighteenth and Nineteenth Century Britain. Part 2. The Sabine Baring-Gould and Thomas Crampton Collections in the British Library. Microform. London: Harvester, 1987. Rolls 17-20. 
Beattie, J. M. Crime and the Courts in England 1660-1800. Princeton: Princeton UP, 1986.

Bodleian Library Broadside Ballads. Bodleian Library, U of Oxford, UK. Web. 1 Dec. 2010.

Bourdieu, Pierre. The Logic of Practice. 1980. Stanford: Stanford UP, 1990.

Bourke, Sir Richard. "Governor Bourke's Proclamation 10 October, 1835 (UK)." London: National Archives of the United Kingdom. Documenting Democracy (Commonwealth of Australia). Web. 10 Feb. 2011.

Brand, Ian. The Convict Probation System: Van Dieman's Land 1839-1854. Hobart: Blubber Head P, 1990.

Brooke, Alan and David Brandon. Bound for Botany Bay: British Convict Voyages to Australia. Kew, Richmond, Surrey: National Archives, 2005.

Coggeshall, W. T. Newspaper Record, Containing a Complete List of Newspapers and Periodicals in the United States, Canada, and Britain. Philadelphia: Lay \& Brother, 1856. HathiTrust. Web. 18 Nov. 2011.

Coldham, Peter Wilson. Emigrants in Chains: A Social History of Forced Emigration to the Americas, 1607-1776. Stroud: Alan Sutton, 1992.

Colley, Linda. Britons: Forging the Nation 1707-1837. 1992. Rev. ed. New Haven: Yale UP, 2009.

Collins, David. An Account of the English Colony in New South Wales. London: Cadell and Davies, 1798. Australiana Facsimile Editions 76. Adelaide: Libraries Board of South Australia, 1971.

Collison, Robert. The Story of Street Literature: Forerunner of the Popular Press. London: J. M. Dent, 1973.

Dickens, Charles. Our Mutual Friend. 1864-65. Oxford: Oxford UP, 2008.

Duffield, Ian. "Problematic Passages: 'Jack Bushman's' Convict Narrative." Representing Convicts: New Perspectives on Forced Labour Migration. Ed. Ian Duffield and James Bradley. London: Leicester UP, 1997. 20-42.

Duffield, Ian, and James Bradley, eds. Representing Convicts: New Perspectives on Convict Forced Labour Migration. London: Leicester UP, 1997.

Dyster, Barrie, ed. Beyond Convict Workers. Sydney: Department of Economic History, University of New South Wales, 1996.

Ekirch, A. Roger. Bound for America: The Transportation of British Convicts to the Colonies, 1718-1775. Oxford, UK: Clarendon, 1987.

Evans, Eric J. The Forging of the Modern State: Early Industrial Britain. 2nd ed. London: Longman, 1996.

Fielding, Henry. Reform Proposals, 1751. Excerpted in Crime and Punishment in England. Eds. Andrew Barrett and Christopher Harrison. London: UCL P, 1999. 136-50.

Foucault, Michel. Discipline and Punish: The Birth of the Prison. Trans. Sheridan, Alan. New York: Vintage, 1979.

Frost, Alan. Convicts and Empire: A Naval Question 1776-1811. Melbourne: Oxford UP, 1980.

Frost, Lucy, and Hamish Maxwell-Stewart, eds. Chain Letters: Narrating Convict Lives. Carlton South, Victoria: Melbourne UP, 2001.

Godfrey, Barry S., and Paul Lawrence. Crime and Justice 1750-1950. Cullompton, Devon: Willan, 2005.

Gramsci, Antonio. Selections from Cultural Writings. Ed. David Forgacs and Geoffrey Nowell-Smith. Trans. William Boelhower. Cambridge: Harvard UP, 1985.

Gretton, Tom. "Last Dying Speech and Confession." Convict Love Tokens: The Leaden Hearts the Convicts Left Behind. Ed. Michele Field and Timothy Millet. Kent Town, So. Australia: Wakefield, 1998. 39-46.

Hepburn, James. A Book of Scattered Leaves: Poetry of Poverty in Broadside Ballads of Nineteenth-Century England. 2 vols. Lewisburg: Bucknell UP, 2000.

Hirst, J. B. Convict Society and Its Enemies: A History of Early New South Wales. Sydney: George Allen \& Unwin, 1983.

Hopkin, David, Valentina Bold, and David Morrison, comps. Glasgow Broadside Ballads. Glasgow: U of Glasgow Library Special Collections. Web. 7 Sept. 2010.

Hughes, Robert. The Fatal Shore: A History of the Transportation of Convicts to Australia, 1787-1868. New York: Random House, 1988.

James, Louis. Print and the People 1819-1851. London: Allen Lane, 1976. 
Jenkins, Philip. "From Gallows to Prison? The Execution Rate in Early Modern England." Crime, Police and the Courts in British History. Ed. Louis A. Knafla. Readings from Criminal Justice History. Westport: Meckler, 1990. 129-49.

Jones, Mary. "Copy of a Letter sent from a Young Woman who was transported from this City." Bristol: Sherring's Cheap Printing Office, n.d. Broadsides Printed at Bristol Between 1700-1840. Vol. 2, \# 415. British Library. Shelfmark: 74/188.c.20.

Maxwell-Stewart, Hamish, and Ian Duffield. "Skin Deep Devotions: Religious Tattoos and Convict Transportation to Australia." Written on the Body: The Tattoo in European and American History. Ed. Jane Caplan. Princeton: Princeton UP, 2000. 118-35.

Morgan, Gwenda, and Peter Rushton. Eighteenth-Century Criminal Transportation: The Formation of the Criminal Atlantic. Houndsmills, Basingstoke, Hampshire: Palgrave, 2004.

Nicholas, Stephen. "The Care and Feeding of Convicts." Convict Workers. Ed. Stephen Nicholas. 180-98.

Nicholas, Stephen, ed. Convict Workers: Reinterpreting Australia's Past. Cambridge: Cambridge UP, 1988.

Nicholas, Stephen, and Peter R. Shergold. "Unshackling the Past." Convict Workers. Ed. Stephen Nicholas. $3-13$.

Oxley, Deborah. Convict Maids: The Forced Migration of Women to Australia. Cambridge: Cambridge UP, 1996.

Palmer, Roy, ed. Birmingham Ballads: Facsimile Street Ballads. Birmingham: City of Birmingham Education Dept., 1979.

. The Sound of History: Songs and Social Comment. Oxford: Oxford UP, 1988.

Philips, David, and Susanne Davies, ed. A Nation of Rogues? Crime, Law and Punishment in Colonial Australia. Melbourne: Melbourne UP, 1994.

Rawlings, Philip. Drunks, Whores and Idle Apprentices: Criminal Biographies of the Eighteenth Century. London: Routledge, 1992.

Reece, Bob. The Origins of Irish Convict Transportation to New South Wales. New York: Palgrave, 2001. Print.

Reid, Kirsty. Gender, Crime and Empire: Convicts, Settlers and the State in Early Colonial Australia. Manchester: Manchester UP, 2007.

Rickard, Suzanne, ed. George Barrington's Voyage to Botany Bay: Retelling a Convict's Travel Narrative of the 1790s. An Impartial and Circumstantial Narrative of the Present State of Botany Bay, In New South Wales ... by George Barrington, now Superintendant of the Convicts at Paramata (c. 1793-94). London: Leicester UP, 2001.

Robson, L. L. The Convict Settlers of Australia. 1965. Carlton, Victoria: Melbourne UP, 1994.

Rowbotham, Judith. "Execution as Punishment in England: 1750-2000." Histories of Crime: Britain 1600-2000. Ed. David Nash and Anne-Marie Kilday. Houndsmills, Basingstoke, Hampshire: Palgrave Macmillan, 2010. 180-202.

Rudé, George. Criminal and Victim: Crime and Society in Early Nineteenth-Century England. Oxford: Clarendon, 1985.

- Protest and Punishment: The Story of the Social and Political Protesters Transported to Australia 1788-1868. Oxford: Clarendon, 1978.

Shaw, A. G. L. Convicts and the Colonies: A Study of Penal Transportation from Great Britain and Ireland to Australia and Other Parts of the British Empire. 1966. Carlton, Victoria: Melbourne UP, 1977.

Summers, Anne. Damned Whores and God's Police: The Colonization of Women in Australia. Harmondsworth, Middlesex: Penguin, 1975.

Tench, Watkin. A Narrative of the Expedition to Botany Bay; with an Account of New South Wales, Its Productions, Inhabitants, \&C. To Which Is Subjoined, a List of the Civil and Military Establishments at Port Jackson. 2nd ed. London: J. Debrett, 1789.

"The Trial and Sentence of Mary Arnold." Seven Dials [London]: Paul, n.d. Broadsides on Murder \#7. British Library. Shelfmark: 74.1888.c.3. 
“The Unhappy Transport, Giving a Sorrowful Account . . L Life of James Revel, . . . with a Word of Advice to all young Men and Women." [Newcastle?]: n.p., n.d. Collection of Broadsides, etc. British Library. Shelfmark: 1875.d.13.

"The Unhappy Transport, Or, the Sufferings of William Dale, Son of a Farmer and Gardener. ..." Seven Dials [London]: Catnach, n.d. Broadsides on Murder \#57. British Library. Shelfmark: 74.1888.c3. Vicinus, Martha. Broadsides of the Industrial North. Newcastle upon Tyne: Frank Graham, 1975.

Vincent, David. Literacy and Popular Culture: England 1750-1914. Cambridge: Cambridge UP, 1989. Ward, Russell. "Felons and Folksongs." 1950s. TS. Australian National Library, Canberra.

Ward, Russell, ed. The Penguin Book of Australian Ballads. Harmondsworth, Middlesex: Penguin, 1964.

Webb, R. K. The British Working Class Reader 1790-1848: Literacy and Social Tension. London: George Allen \& Unwin, 1955. 